\title{
Assessment of Utilization of ICT Resources in Teaching among Tertiary Institution Business Educators in South Nigeria
}

\author{
Okolocha, Chimezie Comfort ${ }^{1} \&$ Nwadiani, Comfort Onaigho ${ }^{2}$ \\ ${ }^{1}$ Department of Vocational Education, Nnamdi Azikiwe University, P. M. B. 5025, Awka, Anambra State, \\ Nigeria \\ ${ }^{2}$ Departmentof Vocational and Technical Education, University of Benin, Benin City, Edo State, Nigeria \\ Correspondence: Nwadiani, Comfort Onaigho, Department of Vocational and Technical Education, University \\ of Benin, Benin City, Edo State, Nigeria. E-mail: nwadianicomfort@yahoo.com
}

Received: October 30, $2014 \quad$ Accepted: December 23, $2014 \quad$ Online Published: February 19, 2015

doi:10.5539/jel.v4n1p1 URL: http://dx.doi.org/10.5539/jel.v4n1p1

\begin{abstract}
This study assessed the utilization of ICT resources in teaching among business educators in tertiary institutions in south Nigeria. Two research questions and two null hypotheses guided the study. Descriptive survey research design was adopted for the study. The population and sample for the study comprised all 240 business educators in colleges of education and universities in south Nigeria. A 28 -item structured questionnaire was used as instrument for data collection. Copies of the instrument were administered on 240 business educators and 213 were returned representing 88.75 percent. Data collected were analyzed using mean and standard deviation for the research questions. The null hypotheses were tested at 0.05 level of significance using inferential statistics of t-test. The findings revealed that the few available ICT resources are rarely utilized in the teaching of business education, ICT resources utilization has high influence on teaching and that business educators encounter several problems such as irregular power supply in the utilization of ICT resources. It was recommended among other things, that government and stakeholders in education should make adequate budgetary allocation for the provision of ICT resources and the identified barriers that stand against effective utilization of ICT should be tackled and removed to better equip products of tertiary institutions to fit into various workplaces.
\end{abstract}

Keywords: utilization, ICT resources, business education

\section{Introduction}

Utilization is the art of putting things or resources that are tangible or intangible to proper use. As applied in this research, it is the proportion of available time (expressed in percentage) that a piece of equipment or facility is operated in the teaching of business education. Business education can be viewed as that aspect of education which equips students with marketable skills, knowledge and attitudes needed for initial employment and advancement in business and related occupations. It also enhances students work orientation and makes the transition from school to the world of work relatively easy. Business education according to Oladipo (2006) has been a major contributor to helping individuals earn money and helping recipients learn how to use wisely the financial and other resources that are available to them.

Kwacha (2007) and Etonyeaku (2009) affirmed that business education has a formidable force that will equip individuals with appropriate skills, knowledge, abilities and competencies that will enable them to be self-employed and self-reliant which lead to sustainable economic development. Aliyu (2006) and Njuku (2006) opined that business education is education aimed at the acquisition and development of suitable skills, competencies knowledge attitude and values which are necessary for entrepreneurship development with emphasis on information and communication technology skills.

Information and Communication Technology (ICT) is a global connection of many different types of computer networks linked together. Anderson and Glem (2003) in their view, referred to ICT as those technologies that are used to access, gather, manipulate and present or communicate information. They include hardware e.g. computers and other devices; software applications and connectivity; access to the internet, local networking infrastructures and video conferencing. 
ICT essentially entails collating, analyzing, processing, manipulating, storing, retrieving, transmitting and communicating of data in different forms which may include audiovisual, audio and visual formats. This broad definition of ICT includes technologies such as radio, television, video, DVD, telephone (land lines and mobile phones), satellite systems, computers, and network hardware and software as well as the equipment and services associated with these technologies such as video conferencing, e-mail and logs. (UNESCO, 2002). World Bank (2002) conceptualized ICT as consisting of hardware, software, networks and media for collecting, storage, processing, transmitting and presenting of information, voice, data, text and images. It is a new development with tremendous potentials on tertiary education in general and business education in particular. At all levels of education ICT can be a pivot of transforming our resources for business education which could result in much awaited technological changes in our nation (CCNA, 2010).

Business Education is defined by Okolocha and Ile (2008) as education for and about business which aim at preparing its student to acquire skills necessary for paid employment or be self-dependent as an entrepreneur and as well be intelligent consumers of goods and services. Anao (2002) outlined the following unique characteristics as it relates to the teaching of business education.

- It is happening at extremely fast pace;

- It is impacting all corners of the globe;

- effects of the revolution are being experienced by all sectors of the society;

- There appears to be no natural rules or law hindering or governing the pace and direction of the revolution;

- The demand for ICT products is insatiable; and

- The generation that has grown up with information technology has developed intuitive means of absorbing and exploiting the capabilities that technology offers, sometimes to the bewilderment of the older generation.

The implication of this is that ICT now places different demands on education in general and business education in particular. Therefore, the concern on how business education curriculum is delivered in Nigerian colleges of education and universities in contemporary times becomes important if our educational system is to be relevant to serve the societal needs in the present age of information. This can be done by utilizing ICT in teaching and learning situation to improve and enhance business education students learning, academic proficiency, effectiveness and efficiency in the modern day world of work. The challenges for the educators in the colleges of education and universities is no longer centred on covering the course content or adopting appropriate teaching or pedagogical aids but embracing ICT in teaching and learning. There is therefore the need for the business educators to be up- to- date in their knowledge and skills especially in ICT and as well as the utilization of these facilities in teaching and learning situations.

The integration of information technology in teaching is a central matter in ensuring quality of business education courses. There are two equally important reasons for integrating ICT into the teaching and learning of business education. Firstly, students would become familiar with the use of ICT, since all jobs in the society today are dependent on ICT. Secondly, the teaching of business education courses utilizing ICT resources will improves the quality of business education graduates thereby making them more effective and efficient. Since business education provides students with requisites skills which are needed for increasing their productive power on any nation. The work force is accordingly motivated to initiate independent productive ventures and carry out skilled works of divergent nature independently. The positive utilization of ICT therefore becomes imperative to business education students, (Aibieyi \& Egbri, 2010). ICT resources are new developments in science and technology and their utilization can equally stimulate relevance of the Nigerian educational sector in general. Mooij (2001) considered ICT as one part of education technology that pays attention to the concepts, utilization and application in the educational process. This in turn requires rethinking and pedagogical re-engineering of classroom environment and its components. This to a large extent would provide opportunities for proactive learning processes that should be based on cooperative values. Ngurukwem (2006) remarked that there is a noticeable role of ICT in integrating and creating pool of educational media, sound, visual, textual and numeric data for effective teaching and learning of business education. These would be meaningful if they have pedagogical utility in a classroom setting to enhance curricula relevance and adoption.

With ICT resources utilization, teaching and learning can be carried out with or without physical or face to face contact as is hitherto the case in the traditional approach. ICT has tremendously and positively affected developments in all facets of human endeavor. Particularly in contemporary times ICT resources utilization in teaching of business education programme in the colleges of education and universities will facilitate knowledge acquisition and dissemination by students within and between various disciplines. In this way, human input is 
reduced to the barest minimum, with better and more effective performance. Acquiring these skills will however enable them cope with and adapt to the challenges of the modern day educational system and world of work.

Onasanya (2010) asserted that most tertiary institutions lecturers in Nigeria lack adequate pedagogical knowledge for effective utilization of ICT resources for teaching. It is uninteresting and common to see Nigerian business education graduates enroll in roadside computer centres to acquire ICT skills which ought to have been mastered in their colleges of education and universities days. There seems to be a gap in the practical skills especially as regards the ICT resources utilization competencies in the present teaching of business education courses. From the studies carried out by Bolaji (2007) and Kelly (2004) it was revealed that ICT application in tertiary institutions fall below expectation. Okwudishu (2005) and Gambari and Okoli (2007) discovered that the non-availability of some ICT resources in schools hamper educators utilization of ICT resources in teaching.

It was observed from the complaints by stakeholders and some employers of labour that business education graduates especially those recruited by local and multi-national private companies could not manipulate basic ICT resources which are the fundamental tools of operations in those companies (Anoke, 2008). This may not be unconnected with the observation that ICT resources are not available and utilized in teaching business education courses in the colleges of education and universities. Students and lecturers have also expressed their dissatisfaction with the use of obsolete equipment, machines like manual typewriters, and other outdated gadgets in teaching and learning when work environment has gone automated. This dissatisfactory situation is one of the reasons for recent strike actions by Colleges of Education and Universities lecturers in Nigeria. Business educators in colleges of education and universities will definitely continue to produce poor quality business education graduates from these institutions if nothing is done to change the situation. This may result in difficulty in getting employment and inability to breakeven as both public and self-employed graduates.

There are however no empirical evidences to ascertain the actual situation regarding the extent of utilization of ICT resources by business educators in colleges of education and universities in south Nigeria. The problem of this study therefore was to assess the extent of utilization of ICT resources utilized in teaching business education courses in colleges of education and universities in south Nigeria.

The study specifically determined:

The extent of utilization of available ICT resources for teaching by business educators in colleges of education and universities with respect to variables of type of institution and gender of business educators.

The different problems business educators in colleges of education and universities encounter in the utilization of ICT resources in teaching business education courses were also studied.

To what extent do business educators utilize available ICT resources for teaching business education courses in colleges of education and universities in south Nigeria? What problems do business educators in colleges of education and universities encounter in the utilization of ICT resources in teaching business education courses?

The following null hypotheses were tested at 0.05 level of significance:

- There is no significant difference in the opinions of business educators in universities and their counterparts in colleges of education regarding the extent of ICT resources utilization in teaching of business education courses.

- There is no significant difference in the opinion of male and female business educators regarding the influence of ICT resources utilization on teaching of business education courses.

- There is no significant difference in the mean ratings of business educators as regards the problems encountered in the utilization of ICT resources for teaching business education courses in colleges of education and universities.

\section{Method}

The study design adopted for this study was descriptive survey because the researcher collected information on the extent of ICT resources utilization from practicing business educator in this area without manipulating any variable. The population of the study comprised 240 business educators in colleges of education and universities in south Nigeria which also served as the sample. Data were collected with structured questionnaire which was divided into two sections: Section A and B. Section A sought demographic information about the respondents while section B sought information on the extent of utilization, influence of utilization on teaching and the problems encountered in the utilization in teaching. Four experts carried out the face and content validity of the instrument. The reliability was determined by administering the questionnaire on twenty business educators outside the sample population. Data collected were analyzed using Cronbach Alpha statistics and the reliability coefficient of 0.86 was obtained. The questionnaire was administered by the researcher with the help of three 
research assistants. Out of the 240 questionnaires distributed 213 copies representing $88 \%$ were retrieved and used for the study. The null hypotheses were tested using t-test statistics at 0.05 level of significance.

\section{Results}

The results of the study from the two research questions answered and test of the three null hypotheses are hereby presented in tables 1, 2, 3, 4 and 5 .

\section{Research Question}

To what extent do business educators utilize ICT resources in the teaching of business education courses in colleges of education and universities in Nigeria?

Table 1. Business educators mean rating on the extent of ICT resources utilization in colleges of education and universities in Nigeria

\begin{tabular}{|c|c|c|c|c|c|}
\hline \multirow[t]{2}{*}{$\mathrm{S} / \mathrm{N}$} & \multirow[t]{2}{*}{$\begin{array}{l}\text { Extent of ICT resources utilized in } \\
\text { teaching business education courses }\end{array}$} & \multicolumn{2}{|c|}{$\begin{array}{l}\text { Institutional mean }(\bar{x}) \\
\text { rating of ICT resources } \\
\text { utilization in }\end{array}$} & \multirow[t]{2}{*}{$\begin{array}{l}\text { Overall } \\
\text { Mean } \\
\text { rating }\end{array}$} & \multirow[t]{2}{*}{ Remark } \\
\hline & & $\begin{array}{l}\text { Colleges } \\
\text { of } \\
\text { Education }\end{array}$ & Universities & & \\
\hline 1 & $\begin{array}{l}\text { Use internet to search } \\
\text { For material for teaching }\end{array}$ & 2.98 & 3.13 & 3.05 & $\begin{array}{l}\text { Sometimes } \\
\text { utilized }\end{array}$ \\
\hline 2 & $\begin{array}{l}\text { Use computer for recording } \\
\text { Students' scores }\end{array}$ & 2.48 & 2.90 & 2.69 & $\begin{array}{l}\text { Sometimes } \\
\text { Utilized }\end{array}$ \\
\hline 3 & $\begin{array}{l}\text { Use search engine to download } \\
\text { Current information }\end{array}$ & 2.25 & 2.21 & 2.23 & $\begin{array}{l}\text { Rarely } \\
\text { Utilized }\end{array}$ \\
\hline 4 & $\begin{array}{l}\text { Use computer to demonstrate } \\
\text { Mastery of subject matter }\end{array}$ & 2.20 & 2.43 & 2.31 & $\begin{array}{l}\text { Rarely } \\
\text { Utilized }\end{array}$ \\
\hline 5 & $\begin{array}{l}\text { Spread sheet grading students } \\
\text { Scripts }\end{array}$ & 2.16 & 2.40 & 2.28 & $\begin{array}{l}\text { Rarely } \\
\text { Utilized }\end{array}$ \\
\hline 6 & $\begin{array}{l}\text { Use computer to assess students } \\
\text { Response/performance }\end{array}$ & 1.96 & 2.08 & 2.02 & $\begin{array}{l}\text { Rarely } \\
\text { Utilized }\end{array}$ \\
\hline 7 & $\begin{array}{l}\text { Use power point to plan for } \\
\text { Teaching }\end{array}$ & 1.85 & 1.92 & 1.88 & $\begin{array}{l}\text { Rarely } \\
\text { Utilized }\end{array}$ \\
\hline 8 & $\begin{array}{l}\text { Use overhead projector for presentation } \\
\text { /delivery lectures }\end{array}$ & 1.80 & 1.99 & 1.89 & $\begin{array}{l}\text { Rarely } \\
\text { utilized }\end{array}$ \\
\hline 9 & Use film strip application as teaching aid. & 1.72 & 1.49 & 1.60 & $\begin{array}{l}\text { Rarely } \\
\text { utilized }\end{array}$ \\
\hline 10 & Use emails to get feedback from Students & 1.72 & 1.89 & 1.80 & $\begin{array}{l}\text { Rarely } \\
\text { utilized }\end{array}$ \\
\hline 11 & $\begin{array}{l}\text { Use facsimile for teacher/students } \\
\text { Interaction }\end{array}$ & 1.64 & 1.40 & 1.52 & $\begin{array}{l}\text { Rarely } \\
\text { utilized }\end{array}$ \\
\hline 12 & $\begin{array}{l}\text { Use multimedia for class management and } \\
\text { control }\end{array}$ & 1.64 & 1.38 & 1.51 & $\begin{array}{l}\text { Rarely } \\
\text { utilized }\end{array}$ \\
\hline
\end{tabular}




\begin{tabular}{llllll}
\hline 13 & $\begin{array}{l}\text { Use emails to assign class work/home } \\
\text { Work }\end{array}$ & 1.60 & 1.92 & 1.76 & $\begin{array}{l}\text { Rarely } \\
\text { utilized }\end{array}$ \\
14 & $\begin{array}{l}\text { Use video conferencing in networking to } \\
\text { networking to other computers while } \\
\text { teaching }\end{array}$ & 1.57 & 1.44 & 1.50 & $\begin{array}{l}\text { Not } \\
\text { utilized }\end{array}$ \\
\hline
\end{tabular}

The data on Table 1 showed that only item nos 1(the use of internet to search for materials) and 2 (use of computers for recording students' scores) with mean rating utilization indices of 3.05 and 2.69 respectively are the ICT resources sometimes used for teaching business education courses in colleges of education and universities. Other ICT resources on the table, items 18-29 showed that they are rarely utilized with mean rating of below 2.50. The responses showed that video conferencing machine is not being utilized in teaching business education with utilization mean rating of 1.50 for both institutions business educators. From the results, it was revealed that ICT resources for teaching of business education courses in the opinion of business educators are rarely utilized in both colleges of education and universities in south south Nigeria.

Research Question 2

What problems do business educators in colleges of education and universities encounter in the utilization of ICT resources in teaching business courses?

Table 2. Mean rating of business educators' on problems of ICT resources utilization in teaching business education in colleges of education and universities

\begin{tabular}{|c|c|c|c|c|c|}
\hline \multirow[t]{2}{*}{$\mathrm{S} / \mathrm{N}$} & \multirow[t]{2}{*}{$\begin{array}{l}\text { Problems of ICT resources utilization } \\
\text { In teaching business education Courses }\end{array}$} & \multicolumn{2}{|c|}{$\begin{array}{l}\text { Business educators } \\
\text { Institutional mean rating in }\end{array}$} & \multirow{2}{*}{$\begin{array}{l}\text { Overall } \\
\text { mean }(\bar{x}) \\
\text { Rating of } \\
\text { problem }\end{array}$} & \multirow[t]{2}{*}{ Ranking } \\
\hline & & $\begin{array}{l}\text { Colleges of } \\
\text { Educations }\end{array}$ & Universities & & \\
\hline 1 & Irregular power supply & 3.01 & 3.37 & 3.19 & $1^{\mathrm{st}}$ \\
\hline 2 & $\begin{array}{l}\text { Lack of access to utilize ICT resources } \\
\text { at will }\end{array}$ & 2.95 & 3.17 & 3.06 & $2^{\text {nd }}$ \\
\hline 3 & $\begin{array}{l}\text { Difficulty in managing all that ICT } \\
\text { resources integration curriculum } \\
\text { requires }\end{array}$ & 2.87 & $3-13$ & 3.00 & $3^{\text {rd }}$ \\
\hline 4 & Inadequate ICT resources & 2.84 & 3.13 & 2.98 & $4^{\text {th }}$ \\
\hline 5 & $\begin{array}{l}\text { Lack of adequate orientation on how to } \\
\text { Integrate ICT into the curriculum }\end{array}$ & 2.83 & 3.00 & 2.91 & $6^{\text {th }}$ \\
\hline 6 & $\begin{array}{l}\text { Lack of computer literacy in the } \\
\text { Utilization of ICT resources }\end{array}$ & 2.81 & 2.79 & 2.80 & $10^{\text {th }}$ \\
\hline 7 & $\begin{array}{l}\text { Lack of technical support to keep ICT } \\
\text { Resources working during instruction }\end{array}$ & 2.79 & 3.06 & 2.92 & $5^{\text {th }}$ \\
\hline 8 & $\begin{array}{l}\text { Insufficient time allotment on the } \\
\text { school time table }\end{array}$ & 2.76 & 2.89 & 2.82 & $8^{\text {th }}$ \\
\hline 9 & $\begin{array}{l}\text { Lack of the required competencies in } \\
\text { the utilization of ICT resources }\end{array}$ & 2.69 & 2.94 & 2.81 & $9^{\text {th }}$ \\
\hline 10 & $\begin{array}{l}\text { Using ICT resources for instruction is } \\
\text { too expensive }\end{array}$ & 2.68 & 2.92 & 2.80 & $10^{\text {th }}$ \\
\hline
\end{tabular}




\begin{tabular}{llllll}
\hline 11 & Difficulty in the utilization of & 2.67 & 2.89 & 2.78 & $12^{\text {th }}$ \\
& Software/hardware & & & \\
12 & Lack of security for ICT resources & 2.67 & 2.71 & 2.69 & $13^{\text {th }}$ \\
13 & $\begin{array}{l}\text { non availability of computer } \\
\text { Laboratory } \\
\text { Frequent changes in the models of the } \\
\text { ICT resources. }\end{array}$ & 2.63 & 3.15 & 2.89 & $7^{\text {th }}$ \\
& & 2.60 & 2.71 & 2.65 & $14^{\text {th }}$ \\
\hline
\end{tabular}

The data on Table 2 showed that the most serious problem business educators' encounter in the utilization of ICT for teaching is that of irregular power supply with overall weighted mean of 3.19 for colleges of education and universities. The second is lack of access to utilize ICT resources with a mean of 3.06 and the difficulty in managing all that ICT resources integration in the curriculum requires with mean of 3.0 for both Colleges of Education and Universities. The least of the problem encountered from the study is frequent changes in the modes of ICT resources with a mean of 2.65 as indicated by business educators' studied.

Institutionally, the information on Table 2 revealed that the identified common problems business educators encounter in their utilization of ICT resources in the teaching are more prevalent in universities. While only item (1) was rated (3.01) by business educators as the most serious problem in colleges of education, seven items (nos. $1,2,13,3,4,7$ and 5) with assessed means which ranged between 3.37 to 3.0 were identified to be very serious problems out of fourteen items listed by business educators in the universities studied.

$\mathrm{HO}_{1}$ There is no significant difference in the opinions of business educators' in colleges of education and their counterparts in the universities regarding the utilization of ICT resources in teaching business education courses.

Table 3. Business educators' opinion in colleges of education and universities regarding the extent of ICT resources utilized in teaching

\begin{tabular}{llrllll}
\hline Type of institution & \multicolumn{1}{c}{$\begin{array}{c}\text { No. of } \\
\text { respondents(N) }\end{array}$} & $\begin{array}{c}\text { Mean } \\
(\overline{\boldsymbol{x}})\end{array}$ & SD & df & t-cal & t-cri \\
\hline College of Education & 129 & 27.57 & 9.430 & 211 & .817 & 415 \\
University & 84 & 28.60 & 8.053 & & & \\
\hline
\end{tabular}

The data in Table 3 revealed that the calculated t-value (.817) is greater than the critical t-value (.415) at 211 degree of freedom and 0.05 level of significance. This showed that there is significant difference in the opinion of business educators in colleges of education and universities regarding the extent of ICT resources that are utilized in teaching business education courses. The hypothesis was therefore not accepted.

$\mathrm{HO}_{2}$ There is no significant difference in the opinions of male and female business educators regarding the influence of ICT resources utilization on the teaching of business education courses.

Table 4. Male and female business educators' rating regarding the influence of ICT utilization on teaching

\begin{tabular}{llrllll}
\hline Gender & \multicolumn{1}{c}{$\begin{array}{c}\text { No. of } \\
\text { respondents(N) }\end{array}$} & $\begin{array}{c}\text { Mean } \\
(\overline{\mathbf{x}})\end{array}$ & SD & df & t-cal & t-cri \\
\hline Male & 122 & 44.36 & 9.249 & 211 & 330 & .742 \\
Female & 91 & 43.93 & 9.436 & & & \\
\hline
\end{tabular}

The result in Table 4 showed that the calculated t-value (.330) is less than the critical t-value (.742) at 211 degree of freedom and 0.05 level of significance. Therefore the hypothesis is accepted, which revealed that there is no significant difference in the opinion of male and female business educators regarding ICT resource influence on the teaching of business education courses. 
$\mathrm{HO}_{3}$ There is no significant difference in the mean rating of business educators in colleges of education and universities as regards the problems encountered in the utilization of ICT resources in teaching business education course

Table 5. Business educators in colleges of education and universities mean rating as regards the problems encountered in the utilization of ICT resources in teaching business education courses

\begin{tabular}{llrllll}
\hline Type of institution & \multicolumn{1}{c}{$\begin{array}{c}\text { No. of } \\
\text { respondents(N) }\end{array}$} & $\begin{array}{c}\text { Mean } \\
(\bar{x})\end{array}$ & SD & df & t-cal & t-cri \\
\hline College of Education & 129 & 38.80 & 11.012 & 211 & -2.171 & .031 \\
University & 84 & 41.67 & 6.223 & & & \\
\hline
\end{tabular}

The information on Table 5 revealed that the calculated t-value $(-2.171)$ is less than the critical t-value (.031) at 211 level of freedom and 0.05 level of significance. The hypothesis is accepted which showed that there is no significant difference in the opinion of business educators. It was concluded that colleges of education and universities business educators encounter problems in the utilization of ICT resources in the teaching of business education courses.

\section{Discussion}

The analysis of business educators' utilization of available ICT resources in teaching of business education courses as shown in Table 1 indicates that business educators rarely utilize ICT resources in the teaching of business education courses. This is in consonance with the submission that ICT resource application in Nigeria schools fall below expectation (Oladipo, 2006; Bolaji, 2007; Kelly, 2004). The emergence of ICT resources demands the new pedagoelectronic approach in the teaching of business education courses in colleges of education and universities. The study carried out by (Onasanya, 2010) agreed with this present finding that there is little or no utilization of ICT resources in teaching business education courses at the tertiary institutions in Nigeria. Utilization of ICT resources in teaching helps to facilitate instruction in schools and classrooms thereby relating the new curricula based on real world challenges. The provision of scaffolds and tolls for assessing teaching and giving educators and students' opportunities to feedback will also be achieved via ICT resources utilization. The only thing that is constant in life is change. Equally, the education sector particularly at the tertiary level is undergoing transformation in its service delivery. Consequently educators will need to avail themselves opportunities that are being provided as regards the popularization of the use of ICT resources in teaching.

The test result also revealed that there is significant difference in the opinion of business educators in colleges of education and universities regarding the ICT resources that are utilized in teaching business education courses. The findings showed that ICT resources utilization in teaching business education is not popular. In the first instance as revealed in the study, not many tertiary institutions have ICT resources and they rarely utilize them. This call for worry, considering the magnitude of information that can be accessed if ICT resources are adequately utilized. In the world of work today, optimal ICT resources utilization is inevitable; for no office can operate effectively today without ICT resources. Because ICT resources were assessed to be more in supply in colleges of education, it is not surprising therefore that those business educators in colleges of education utilize ICT resources more in teaching than their counter parts in universities. This situation calls for serious concern it is expected that business educators' in universities ought to utilize more ICT resources in teaching business education. Unfortunately, business education programmes in universities in south Nigeria lack adequate ICT resources hence not adequately utilized in the teaching of business education courses. This ugly situation is one of the reasons why Colleges of Education and Universities Lecturers in Nigeria embarked on National strike action demanding government concern and adequate funding of tertiary institutions for improved teaching and learning through adequate provision of equipment, facilities and ICT resources inclusive.

Very strongly it is the opinion of the researchers that provision of ICT resource is a matter of stakeholders commitment to and how much business education is perceived as a relevant programme in the school system. This finding is corroborated by the works of (Aduwa-Ogiegbean \& Iyamu, 2005; Aibieyi \& Egbri, 2010) when they asserted that ICT resources utilization in teaching though low, provide unlimited opportunities for students and educators. Business education like all other vocational education courses requires the utilization of ICT resources in teaching. It must be noted that ICT resources utilization for teaching business education programme 
as an innovation like most other new ones, requires time before acceptance and consequently utilization. While some may resist, others though usually few, may at the same time adopt.

The t-test results revealed that there is no significant difference in the opinion of male and female business educators regarding ICT resources influence on the teaching of business education programme. Business educators in colleges of education and universities agreed that ICT resources have both high and moderate influence on the teaching of business education. This is in agreement with the findings CCNA (2010) which confirmed numerous influences of ICT resources utilization on teaching. ICT resources utilization in teaching contributes immensely to effective teaching. A striking revelation is that female business educators are rated higher than male business educators in terms of the mean rating on the extent of ICT utilization influence on the teaching of business education programme. Actually, ICT resources require some measure of patience in their utilization. It is the opinion of many people that women are more patient than men. Some aspect of business education programme like office technology and management are dominated by females and hence may probably be more receptive to innovation.

The t-test result also revealed that there is no significant difference in the mean rating of business educators in colleges of education and universities regarding the problems business educators encountered in the utilization of ICT resources in the teaching of business education courses. It showed that both colleges of education and university business educators are faced with problems such as irregular power supply, lack of ICT resources, lack of technical support etc. This is in consonance with the studies of Okwudishu (2005) and Gambari and Okoli (2007) that numerated the problems tertiary institutions business educators encounter in the utilization of ICT resources in teaching business education courses.

\section{Conclusion}

Based on the findings of the study, it was concluded that business educators opinioned that utilization of ICT resources in teaching to be very low in both colleges of education and universities.ICT resources utilization in teaching has significant influence on teaching and that business educators encounter similar problems in the utilization of ICT resources in teaching of business education courses. The situation calls for urgent and persuasive strategies if actually Nigerian government and stakeholders wants institutions to produce quality graduates that will compete with their counterparts in the global labour market bearing in mind that ICT is now inevitable in the society.

\section{Recommendations}

The following recommendations are suggested for policy options.

1) Government and other relevant stakeholders in education should provide adequate ICT resources for the teaching of business education courses in tertiary institutions. This will enable teachers to effectively utilize them in the classroom and at the same time help to equip students with appropriate ICT skills needed for effective functioning in the modern electronic age.

2) In-service training programme such as seminars, on-the-job retraining and retraining programmes, workshops on ICT resources utilization should be mounted on a regular basis for serving business educators in tertiary institutions. This will enable them learn and up-date existing ICT resources utilization competencies that are constantly changing.

3) Relevant authorities should make adequate power supply of various sources including renewable energy available continually. This is necessary since ICT equipment cannot be utilized effectively without power supply.

4) ICT agencies should assist with free distribution of ICT resources to tertiary institutions as their cooperate social responsibility to communities.

Where they are located. Free donation of ICT equipment will help communities of practice to utilize them since findings shows that non utilization is associated with non-availability of ICT resources.

\section{References}

Aduwa-Ogiegbaen, S. E., \& Iyamu, E. O. (2005). Using Information and communication technology in secondary schools in Nigeria: Problems and Prospects. Educational Technology and Society, 8(1), 104-112.

Aibieyi, S., \& Egbri, J. N. (2010). Office management and information system. Benin City Ethiope Publishing Corporation. 
Ajagun, G. A. (2003). The development of ICT skills through the national computer education curriculum of Primary School. In M. A. G. Akali (Ed.), Information and Communication Technology and Science, Technology and mathematics Education. Lagos: STAN Publisher.

Akudolu, L. R. (2002). Information and communication technology (ICT) Centred education: A necessity for national development. In R. C. Ebenebe, \& L. R. Akudolu (Eds.), Education for National Development and Integration. Awka: Faculty of Education, Nnamdi Azikiwe University.

Aliyu, M. A. (2006). Perception of business educators on business education in meeting NEEDS objectives. Business Education Journal, 111 (1), 67-72.

Anao, A. R. (2002). Positioning Nigeria for effective response to the challenges of emerging technologies and globalization.

Anderson, J., \& Glen, A. (2003). Building capacity of teachers facilitators in technology-pedegogy integration for improved teaching and learning. Retrieved January 20, 2012, from http://www.unescobic.org/file $\mathrm{min} /$ user-upload/ict/ebooks/ict building capacity/building capacity.p.d.f

Anoke, F. C. (2008). Economics of providing computer for the integration of information communication technology (ICT) in Nigeria schools (pp. 192-196). Proceedings of the first international conference of Faculty of Education. University of Nigeria, Nsukka.

Azuka, E. B. (2005). Opportunity of information and communication technology in business education in secondary schools. Business Education Book of Readings, 1(5), 11-21.

Bolaji, L. (2001). ICT the hopes and reality in school (1st ed.). Ibadan University Press.

CCNA. (2010). ICT as an agent of transferring vocational and technical programme: CCNA chambers: J. (1990). Wiring media CCNA exploration.

Etonyeaku, E. A. C. (2009). Quality assurance for youth empowerment through Business education and entrepreneurship education for national development. Nigeria Vocational Journal, 13(1).

Ibigbami, D. B. O. (2004). Improving the national standard for business education teacher. National Association of Business Education (NABE), 1, 41.

Kelly, T. (2004). Learning with ICT in school (3rd ed.).Uyo: Abaam Publishing.

Kwacha, P. Z. (2007). The imperative of ICT for teachers in Nigeria higher education. Merlot Journal of Online Learning and Teaching, 3(4).

Mooji, T., \& Smeet, E. (2001).Modeling and supporting ICT implementation in secondary schools. Computer and Education, 36, 265-281. http://dx.doi.org/10.1016/S0360-1315(00)00068-3

Ngurukwen, T. L. (2005). Information technology as instrument for management transformation. Retrieved October 6, 2011, from http://www.ncc.org.u/c

Njoku, C. U. (2006). Business education and value orientation for national economic empowerment and development. Paper presented at Owo 2006. Annual conference of the Association of Business Education of Nigeria (ABEN).

Okolocha, C. C., \& Ile, M. C. (2008).The role of Business education in promoting entrepreneurial skills in women. Business Education Journal, 1(2), 221-232.

Okwor, F. A. (2002). Science and technological issues for education in the information Age. Interdisciplinary Educational Journal (INTEJ), 18-32.

Okwudishu, C. H. (2005). Awareness and use of information and communication technology and secondary schools: First results from the ICTs in school survey, 2003-2004. Retrieved from http://www.stacan.ca/English/research/81-595.MIE 2004 07.pdf

Oladipo, A. (2006). Enhancing entrepreneurial skills through business programme in information technology era. Business Education Books of Readings, 1, 55-67.

Onasanya, S. A., Shehu, R. A., Oduware, R. O., \& Shettu, L. A. (2010). Higher institutions lecturers' attitude towards integration of ICT into teaching and research in Nigeria. Journal of Information Technology, 2, 1-10. http://dx.doi.org/10.3923/rjit.2010.1.10

UNESCO. (2002). Information and communication technologies in teacher education: A planning guide. Paris, NNESCO. 
World Bank. (2002). Constructing knowledge societies: New challenges for tertiary education. Washington.

\section{Copyrights}

Copyright for this article is retained by the author(s), with first publication rights granted to the journal.

This is an open-access article distributed under the terms and conditions of the Creative Commons Attribution license (http://creativecommons.org/licenses/by/3.0/). 